Research Article

\title{
Study on Overburden Stability and Development Height of Water Flowing Fractured Zone in Roadway Mining with Cemented Backfill
}

\author{
Yu Dong $\mathbb{D}^{1,2}$ Yucheng Huang, ${ }^{2}$ Jifang Du $\mathbb{D}^{1,2}$ and Fei Zhao ${ }^{3}$ \\ ${ }^{1}$ School of Management Science and Engineering, Shandong Technology and Business University, Yantai 264005, China \\ ${ }^{2}$ School of Resources and Safety Engineering, China University of Mining \& Technology (Beijing), Beijing 100083, China \\ ${ }^{3}$ Shanxi Anmei Mining Design \& Engineering Co.,Ltd, Taiyuan 030032, China
}

Correspondence should be addressed to Yu Dong; dongyu1987@sdtbu.edu.cn

Received 28 December 2020; Revised 27 January 2021; Accepted 3 March 2021; Published 19 March 2021

Academic Editor: Guangchao Zhang

Copyright (c) $2021 \mathrm{Yu}$ Dong et al. This is an open access article distributed under the Creative Commons Attribution License, which permits unrestricted use, distribution, and reproduction in any medium, provided the original work is properly cited.

In order to explore the stability of overburden rock and the development height of water flowing fractured zone in roadway filling mining, based on the movement and deformation mechanism of overburden rock, the mechanical analysis of overburden stability and failure was carried out, and the mechanical model of main roof rock beam was established, and the ultimate span and limit deflection of rock beam fracture were deduced. Combined with the mechanical model of the main roof fractured rock, the basis for the judgment of overburden failure developing to fractured zone is given in this paper. Taking a coal mine roadway backfill under water-bearing stratum as an example, based on the equivalent mining height, the theoretical calculation and analysis are carried out on the stability of overburden rock and the height of water flowing fractured zone. The reliability of the theoretical analysis is verified compared with the empirical formula and the numerical simulation results. The results showed that the water flowing fractured zone developed to the bottom of no. 7 glutenite, with a height of $32.5 \mathrm{~m}$, slightly less than the calculation result of the empirical formula. The thickness of the waterproof coal pillar was $39.8 \mathrm{~m}$, which was much less than the distance from the aquifer to the coal seam and can be mined safely.

\section{Introduction}

China is rich in coal resources, which occupy a dominant position in China's primary energy consumption [1]. In the process of underground coal mining, the stress balance state of the overlying rock is destroyed with the coal mining in turn, resulting in the movement, deformation, and even destruction of the overlying rock [2-6]. According to the movement and deformation of overlying strata, the overlying strata after mining can be divided into caving zone, fractured zone, and bending subsidence zone [7-9]. After the fissures of overburden caving fault connect with each other, the water conducting channel and water conducting fractured zone are formed $[10,11]$. By studying the stability of overburden rock and the development of water flowing fractured zone, it is of great significance to prevent water disaster, mining under water, and protect water resources.
The overburden damage and the development of water flowing fractured zone caused by coal mining have been studied by scholars and put forward a series of safety technology theories and measures for mining under water [12-17]. Some scholars have studied the movement of overlying rock and the evolution of fractured zone by means of simulation experiment [18-23]. In terms of model algorithm prediction, some other scholars have deduced the prediction model of the development height of water flowing fractured zone through field measurement, mathematical theoretical calculation, and mechanical model construction $[12,24,25]$. The above research provides a basis for coal mining under rivers. However, mining induced fractures and overlying strata deformation need further exploration from the perspective of surface water and aquifer mining.

With the development of mine backfill and the trend of green mining in recent years, people pay more and more 
attention to the control of overburden movement, deformation, and damage by backfill in coal mines. The research on the influence factors and control effect of backfill mining to control the movement and deformation of overburden is becoming more and more mature. Zhang et al. [26-28] have carried out theoretical and experimental research on comprehensive mechanized solid backfill mining technology, which provides theoretical basis and ideas for related analysis of overburden movement and surface subsidence in dense backfill mining. Based on the control theory of rock strata, Zhang et al. [29-32] comprehensively and systematically studied the movement and surface subsidence characteristics of gangue backfill overburden. Zhu et al. [33], Yan et al. [34], and Huang et al. [35] studied the structure and movement characteristics of overlying strata in different stages by means of physical experiments and revealed the mechanism of controlling strata settlement by filling mining. Yang and Qiu [36] and Feng and Zhang [37] studied the law of overlying rock movement in backfill mining by numerical simulation. The analysis results show that the filling quality and ratio play a significant role in controlling the movement, deformation, and failure of overburden.

With urban development and the level of coal mining enhanced in China, the proportion of coal mining under buildings, railways, and water bodies that is called the three-underground mining increases rapidly. In order to fully recover the safety coal pillars left by the "threeunderground" pressure coal caving method in some mining areas, the backfill mining of local coal pillars should be carried out safely and effectively. However, the roadway mining with cemented backfill method has the advantages of small capital investment, flexible technology, and small interaction between mining and filling processes, which is more suitable for local backfill mining. How to effectively control the deformation of surrounding rock and overlying strata and control the surface subsidence is worthy of further study. In view of this, based on the basic principle of roadway backfill mining, this paper analyzes the movement and deformation characteristics of overburden rock, establishes the mechanical model of main roof rock beam of backfill mining under aquifer, and discriminates the development of overburden failure to fractured zone.

Based on the equivalent mining height of backfill mining, the theoretical calculation and numerical model of overlying rock water flowing fractured zone height are carried out. This paper intends to study the stability of overburden rock and explore the development height of water flowing fractured zone after instability failure by comparative analysis.

\section{Mechanism of Overburden Movement and Deformation in Roadway Mining with Cemented Backfill}

The roadway cemented backfill mining technology takes gangue, fly ash, and cement as filling materials and dries the roadway at a certain distance in the planned area. The filling slurry made from the ground filling station is transported to the underground working face through pipelines. Then, the roadway is filled. After the filling materials are solidified, the coal pillars between the filled-roadways are recovered and filled. Because the filling materials can not only realize self-supporting and bear large bearing pressure after reaching the setting strength but also can provide active side limiting pressure for coal pillar. Therefore, it is not necessary to set up permanent coal pillar to realize full mining and full filling of roadway and maximize the recovery of coal resources.

Taking three cycles as an example, the circulation diagram of roadway cemented backfill mining is shown in Figure 1.

According to Figure 1, the strata movement above the coal seam of roadway backfill mining can be divided into three stages. First of all, as the coal mined out in the way of driving roadway, when the filling slurry is not filled into the filling roadway, the roof strata above the roadway will have a certain amount of bending subsidence due to the effect of overburden pressure. The first cycle of roadway backfill takes driving two filling roadways as an example, and the schematic diagram of strata movement is shown in Figure 2.

Secondly, when the filling slurry is filled into the unfilled-roadway, along with the sequence of roadway backfill mining, the filling width increases, and the roof strata gradually move downward with the compression of the filling body after contacting with the filling body. When the subsidence of the roof rock exceeds the limit deflection that the rock stratum can bear, the roof rock fracture occurs. The second cycle of roadway backfill takes driving and filling two unfilled-roadways as an example. The schematic diagram of strata movement is shown in Figure 3.

Finally, when the subsidence is large, the roof strata may break regularly on the filling body. With the filling cycle going on, the filling width continues to increase, the fractured rock stratum and filling body are gradually compacted by the selfweight stress of overburden rock, and the overlying strata move downward. When the subsidence exceeds the ultimate deflection that the rock itself can bear, the rock will break down and the fracture will develop upward until a certain rock stratum does not break. After that, with the continuous filling, the roof strata gradually tend to be stable. Taking the first filling roadway of the third cycle driving and filling as an example, the schematic diagram of strata movement is shown in Figure 4.

Therefore, in the process of roadway filling mining, as long as a certain filling rate is reached, the main failure form of overburden movement is fracture due to the slow settlement and reduction of filling body, and its failure height is significantly lower than that of caving mining, which is also the fundamental reason why the roadway filling mining under water can reduce the width of waterproof coal pillar and increase the upper limit of mining. The rock pillar can be reduced and the upper limit of mining can be increased. The water flowing fractured zone of roadway filling mining is shown in Figure 5. 


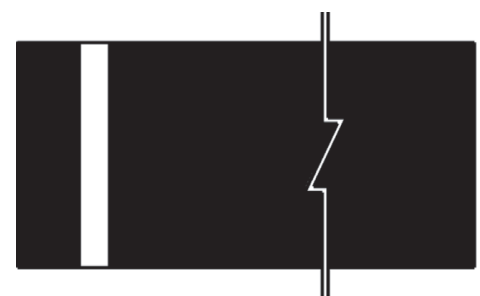

(a1)

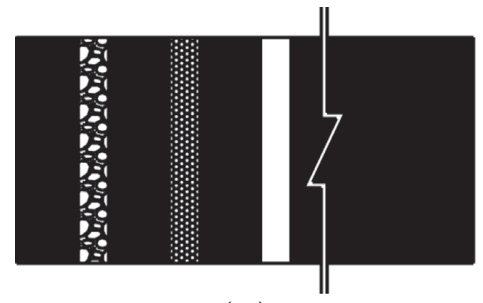

(a3)

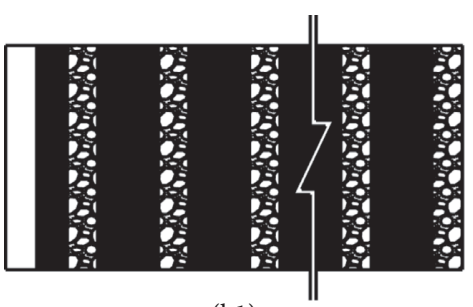

(b1)

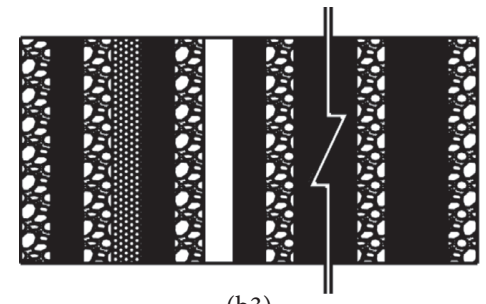

(b3)

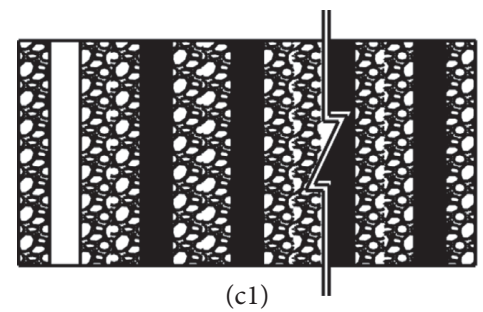

Second cycle

First cycle

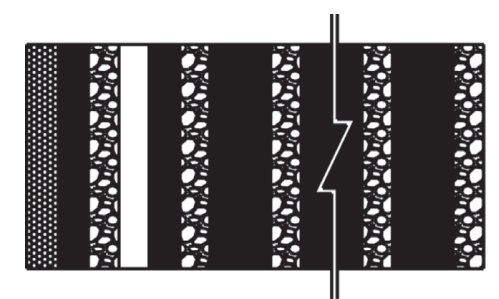

(b2)

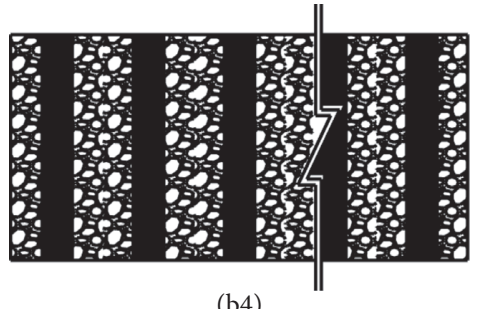

(b4)

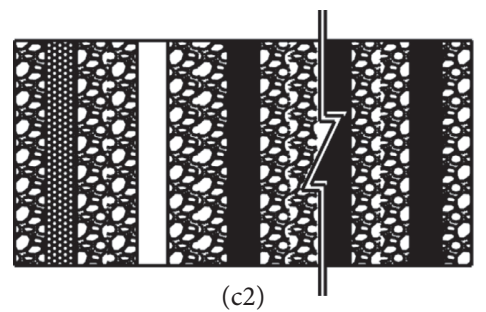

(c2)

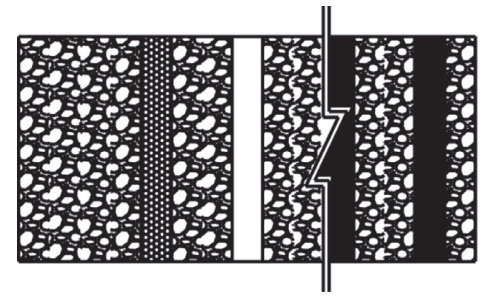

(c3)

Third cycle

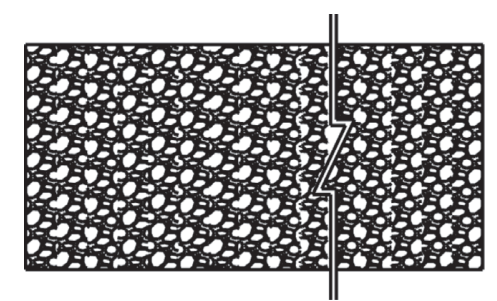

(c4)

Coal

Unfilled-roadway

Completely solidified filling body

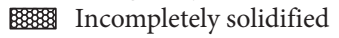
filling body

FIGURE 1: Cycle diagram of roadway mining with cemented backfill. 


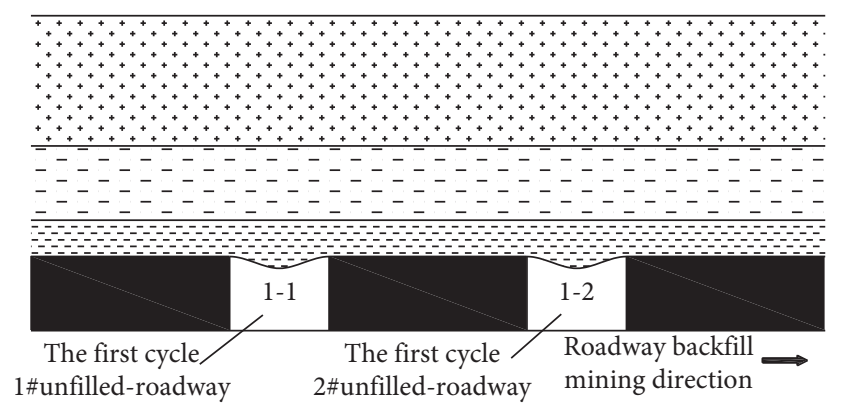

FIGURE 2: Schematic diagram of the first stage of strata movement.

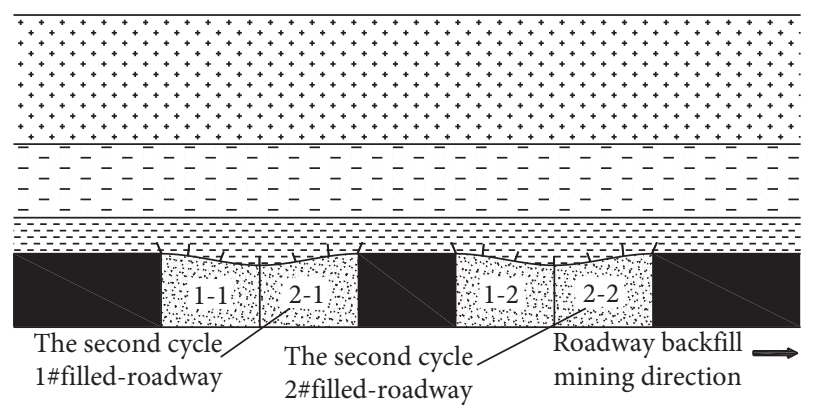

FIgURE 3: Schematic diagram of the second stage of strata movement.

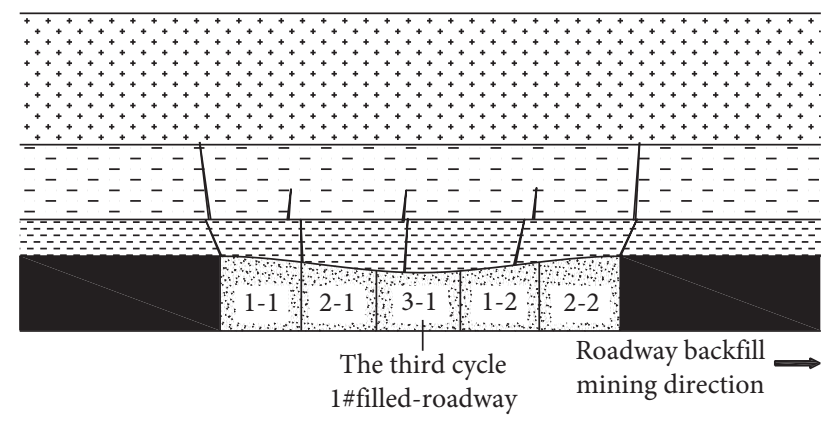

FIGURE 4: Schematic diagram of the third stage of strata movement.

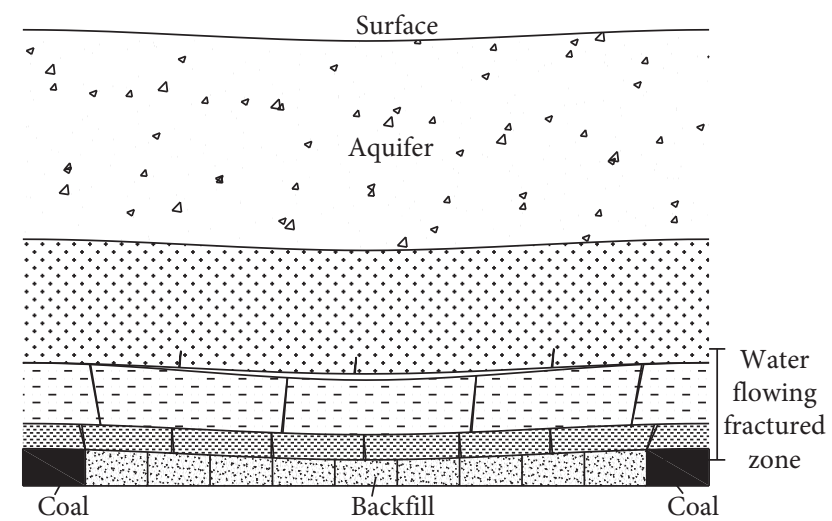

FIGURE 5: Schematic diagram of water flowing fractured zone in backfill mining.

\section{Mechanical Analysis of Overburden Deformation and Failure in Roadway Backfill Mining}

3.1. Equivalent Mining Height of Backfill Mining. In the process of roadway backfill mining, with the unfilledroadway backfill in turn, the filling body gradually replaces the coal body and plays a supporting role in the overlying strata. With the filling body being compacted slowly, the damage degree of overburden rock caused by backfill mining is equivalent to that caused by caving mining of thin coal seam with equivalent mining height.

The schematic diagram of equivalent mining thickness of filling mining is shown in Figure 6, and the equivalent mining height formula of filling is obtained as follows:

$$
M_{e}=M_{1}+M_{2}+M_{3} \text {. }
$$

In the formula, $M_{e}$ is the equivalent mining height of the filling body; $M_{1}$ is the roof subsidence without backfill; $M_{2}$ is the distance between the filling body and the roof; and $M_{3}$ is the compression amount of the filling body.

For $M_{1}, M_{2}$, and $M_{3}$,

$$
\begin{aligned}
& M_{1}=\eta \cdot M, \\
& M_{2}=(1-\varepsilon) \cdot M, \\
& M_{3}=\delta \cdot \varepsilon \cdot M .
\end{aligned}
$$

In the formula, $\eta$ is the roof subsidence rate before filling, $\% ; \varepsilon$ is the filling rate, $\% ; \delta$ is the compression rate of the filling body, \%; and $M$ is the mining thickness of the coal seam, $m$.

Therefore, the equivalent mining height formula of filling is transformed into

$$
M_{e}=\eta \cdot M+(1-\varepsilon) \cdot M+\varepsilon \cdot M .
$$

There are two conditions for overburden failure in the process of roadway backfill mining [38]: (1) there is a certain subsidence space in the strata, and the ultimate deflection of the strata is less than the subsidence space of the strata; (2) the tensile stress of the strata exceeds the tensile strength of the strata.

3.2. Mechanical Model of Overlying Strata Fracture. In the process of roadway backfill mining, when the subsidence space between the filling body and the upper immediate roof is greater than the limit deflection of the immediate roof, the immediate roof will break after reaching the limit span. With the development of roadway backfill mining, the filling width increases, and the fractures gradually develop upward. Above the regular zone, there are fractured zone and continuous deformation zone. The damage change pattern is similar to that of caving method, but the damage degree and development height are relatively small. The schematic diagram is shown in Figure 7.

Above the immediate roof, along the coal seam dip direction, the main roof rock beam with unit width is taken. 


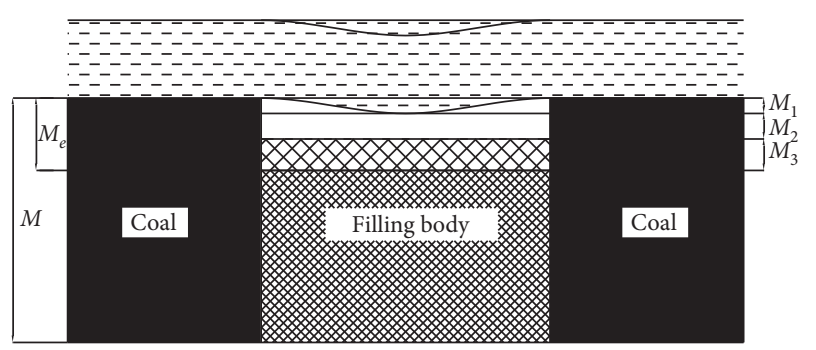

FIgURE 6: Schematic diagram of equivalent mining height in backfill mining.

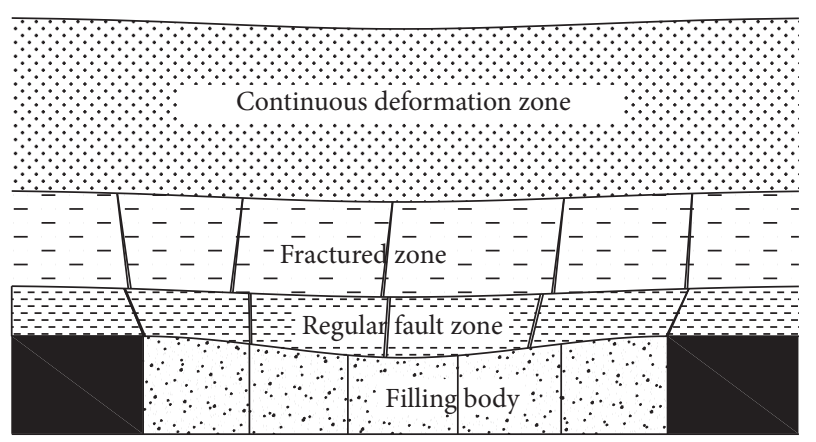

FIGURE 7: Schematic diagram of the roof regularly caving zone with roadway backfill.

The two ends of the main roof are clamped by the overlying strata, which are regarded as fixed support, and the load is set as $p_{Z}$. When the span of the main roof rock beam $l$ is within the limit span range, the rock beam does not break, so it can be considered as continuous. Therefore, on the basis of direct roof fracture, the mechanical model of main roof rock beam is established, as shown in Figure 8.

(1) When the span of the rock beam $l$ reaches the limit span $l_{l}$, and the limit deflection value of the rock beam is less than the sinking space under the rock beam, the rock beam will fracture when the immediate roof of the fracture above the filling body does not contact with the main roof rock beam. Therefore, for the main roof rock beam loaded with $p_{Z}$, there are

$$
E_{l} I_{l} \frac{d^{4} W(x)}{d x^{4}}=p_{z}
$$

In the formula, $E_{l}$ is the elastic modulus of the main roof rock beam and $I_{l}$ is the moment of inertia of the main roof rock beam. The deflection equation of main roof beam is set as follows:

$$
\begin{aligned}
W(x)= & \frac{p_{z}}{E_{l} I_{l}}\left[\frac{1}{24}\left(x+\frac{l}{2}\right)^{4}+c_{1}\left(x+\frac{l}{2}\right)^{3}\right. \\
& \left.+c_{2}\left(x+\frac{l}{2}\right)^{2}+c_{3}\left(x+\frac{l}{2}\right)+c_{4}\right] .
\end{aligned}
$$

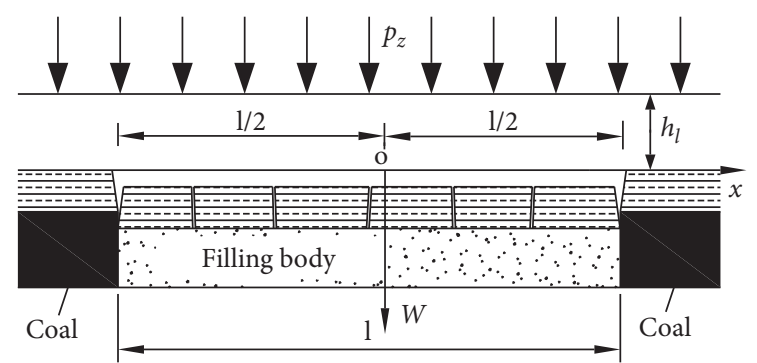

Figure 8: Mechanical model of the main roof under stress.

Due to the fixed support at both ends of the beam, there are

$$
\begin{aligned}
& \left.W(x)\right|_{x=-\frac{l}{2}}=\left.W(x)\right|_{x=-\frac{l}{2}} ; \\
& \theta=\left.\frac{\mathrm{d} W(x)}{\mathrm{d} x}\right|_{x=-\frac{1}{2}}=\left.\frac{\mathrm{d} W(x)}{\mathrm{d} x}\right|_{x=\frac{l}{2}}=0 .
\end{aligned}
$$

The deflection function of the beam is obtained as follows:

$$
W(x)=\frac{p_{z}}{24 E_{l} I_{l}}\left[\left(x+\frac{l}{2}\right)^{4}-2 l\left(x+\frac{l}{2}\right)^{3}+l^{2}\left(x+\frac{l}{2}\right)^{2}\right] .
$$

If the tensile stress at any point in the beam is set as $\sigma$, then when $\sigma=R_{T}$, the tensile stress of rock stratum at this point reaches the tensile strength of rock stratum, and the rock stratum will crack at this point. Then, the ultimate span of rock beam can be obtained by material mechanics method. The limited span $l_{l}$ and limited deflection $W_{l}$ of rock beam are

$$
\begin{gathered}
l_{l}=h_{l} \sqrt{\frac{2 R_{T}}{p_{z}}}, \\
W_{t}=\frac{p_{z} l^{4}}{384 E_{l} I_{l}} .
\end{gathered}
$$

In the formula, $h_{l}$ is the thickness of main roof rock beam and $R_{T}$ is the tensile strength of main roof rock beam.

(2) In the process of roadway filling mining, when the filling rate of filling mining is high, close to $100 \%$ filling, and the elastic modulus of filling body is large, the compression deformation is very small under the action of overlying strata load, and the given deformation of roof rock is also very small, which cannot reach the limit deflection of roof rock breaking, the rock beam will not be broken, and the overlying strata will only form bending subsidence zone, as shown in Figure 9.

To sum up, the abovementioned methods can be used for the correlation analysis of overburden fracture for each key 


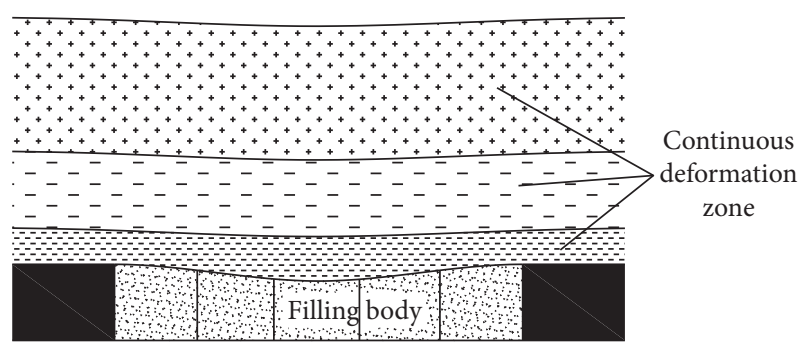

FIgURE 9: Schematic diagram of immediate roof bending deformation with roadway backfill.

stratum above the main roof. The breaking of key stratum will lead to the simultaneous breaking of local overburden or all overburden rocks within its control range, which has an important impact on the development height of overlying rock water flowing fractured zone in roadway filling mining under water body. Therefore, finding out the key strata of overburden and analyzing whether it is broken can further determine the development height of water flowing fractured zone.

\subsection{Identification of Overburden Failure Developing to} Fractured Zone. The main roof rock beam will fracture when it reaches the limit deflection, as shown in Figure 10. When the main roof rock beam enters the fault zone, the hinged structure is formed between the rock blocks. In Figure 10, two adjacent fault main roof rock blocks are taken for analysis, and the stress analysis of the main roof fracture block is shown in Figure 11.

In Figure 11, the three hinged points of three hinged arches are $\mathrm{A}, \mathrm{B}$, and $\mathrm{C}, F$ is the horizontal thrust, $R_{A}$ and $R_{B}$ are the friction forces, $q$ is the load of beam point of fracture body, $y$ is the rock block width, $m$ is the rock block thickness, and $s$ is the rock block subsidence. According to the three hinged arch equilibrium formed by the main roof fault block [39], it can be concluded that

$$
m-u-s>0 \text {. }
$$

In the formula, $\mathrm{u}$ is the height of arch hinge point extrusion contact surface of rock block; $\alpha$ is the return angle of main roof rock block; $s=y \sin (\alpha / 2)$; and $u=1 / 2(m-y \sin (\alpha / 2))$.

Formula (12) is further sorted out as follows:

$$
m>\frac{3}{2} y \sin \frac{\alpha}{2}=\frac{3}{2} s .
$$

The maximum subsidence of the rock block is the height $v$ of the free sinking space in the lower part. Therefore, there are

$$
m>1.5 v
$$

The establishment of formula (14) is one of the conditions for judging the development of overburden failure to fractured zone.

3.4. Determination of Free Subsidence Space of Rock Stratum. Due to the fragmentation and expansion of the rock block, the free space height between the broken rock block and its

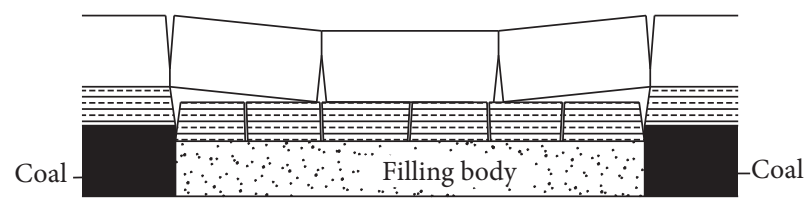

Figure 10: Schematic diagram of main roof rock beam fracture.

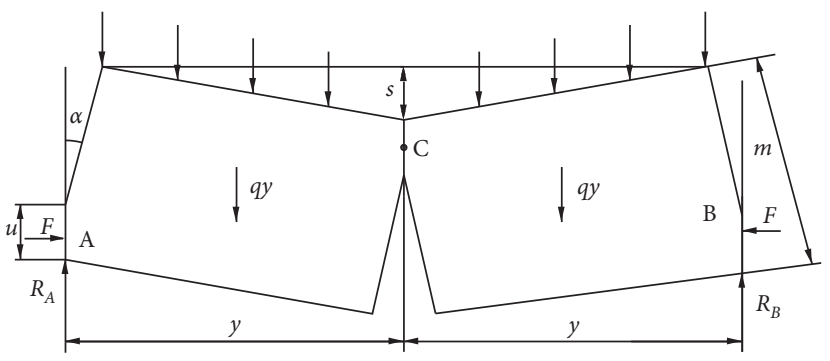

FIGURE 11: Stress analysis of main roof fault block.

overlying strata gradually decreases with the development of the overlying rock ring from the bottom to top. It is necessary to consider the fragmentation and swelling of rock strata within the range of regular fault zone and fractured zone. Because the coefficient of crushing expansion of fractured rock in the final compaction state tends to be the residual coefficient, so the calculation is considered as the residual coefficient. Then, the allowable free subsidence space of each stratum [40] is as follows:

$$
u_{i}=M_{e}-\sum_{i=1}^{n}\left(k_{c i}-1\right) \cdot h_{i} .
$$

In the formula, $u_{i}$ is the free subsidence space of each stratum; $M_{e}$ is the equivalent mining height of filling body; $k_{c i}$ is the residual crushing expansion coefficient of overlying rocks; and $h_{i}$ is the thickness of overlying strata.

\section{Theoretical Calculation of Development Height of Water Flowing Fractured Zone in Overburden}

4.1. Engineering Geological Conditions. A mining area in Northwest China is located $2.5 \mathrm{~km}$ away from the river. The aquifer sand layer at the bottom of the riverbed covers the upper part of the coal bearing strata, which is a strong aquifer with a thickness of 20-23 m. The main mining no. 6 coal seam is $15 \mathrm{~m}$ thick, which belongs to extra-thick coal seam, the dip angle of coal seam is $5^{\circ}$ to $8^{\circ}$, and the mining height of each layer is $3 \mathrm{~m}$. The roof glutenite with sandstone is medium hard without good water resisting layer. The stratification and mechanical parameters of overburden are shown in Table 1.

\subsection{Judgment of Key Strata and Calculation of Overlying} Strata. According to the judgment method of key stratum [40], the overlying rock of the coal seam in the mine is judged. The calculation and analysis results are shown in Table 2 in combination with Table 1. 
TABLE 1: Stratification and mechanical parameters of overlying strata in coal seam.

\begin{tabular}{|c|c|c|c|c|c|c|}
\hline $\begin{array}{l}\text { Layer } \\
\text { number }\end{array}$ & Lithology & $\begin{array}{c}\text { Cumulative } \\
\text { depth (m) }\end{array}$ & Layer thickness (m) & Bulk density $\left(\mathrm{KN} / \mathrm{m}^{3}\right)$ & Tensile strength $(\mathrm{MPa})$ & Elastic modulus (GPa) \\
\hline 1 & Topsoil & 4.8 & 4.8 & 13.8 & - & - \\
\hline 2 & Gravelly sand & 28.98 & 23.18 & 24 & - & - \\
\hline 3 & Glutenite & 48.98 & 20 & 26.2 & 1.4 & 5 \\
\hline 4 & Sandy mudstone & 54.67 & 5.69 & 25.5 & 1.0 & 3 \\
\hline 5 & Glutenite & 81.97 & 27.3 & 26.4 & 1.6 & 5.1 \\
\hline 6 & Coal & 85.04 & 3.07 & 14 & 0.84 & 2 \\
\hline 7 & Glutenite & 107.01 & 21.97 & 26.4 & 1.7 & 5.2 \\
\hline 8 & Coal & 109.01 & 2 & 14 & 0.82 & 2 \\
\hline 9 & Sandy mudstone & 124.01 & 15 & 25.8 & 0.9 & 3 \\
\hline 10 & Coal & 126.51 & 2.5 & 14 & 0.85 & 2 \\
\hline 11 & Sandstone & 135.31 & 8.8 & 26.2 & 1.8 & 10.4 \\
\hline 12 & Glutenite & 139.51 & 4.2 & 26.4 & 1.5 & 4.8 \\
\hline 13 & No. 6 coal & 154.51 & 15 & 14 & 0.85 & 2 \\
\hline
\end{tabular}

TABLE 2: Load of overlying strata and identification of key strata above coal seam.

\begin{tabular}{lcccc}
\hline Layer number & Lithology & Layer thickness $(\mathrm{m})$ & Key stratum & Load $(\mathrm{kPa})$ \\
\hline 2 & Gravelly sand & 23.18 & - & - \\
3 & Glutenite & 20 & - & 1146.56 \\
4 & Sandy mudstone & 5.69 & Main key stratum & 145.1 \\
5 & Glutenite & 27.3 & - & 1621.85 \\
6 & Coal & 3.07 & Inferior key stratum & 42.98 \\
7 & Glutenite & 21.97 & - & 622.33 \\
8 & Coal & 2 & - & 28 \\
9 & Sandy mudstone & 15 & 414.31 \\
10 & Coal & 2.5 & Inferior key stratum & 35 \\
11 & Sandstone & 8.8 & - & 279.5 \\
12 & Glutenite & 4.2 & \multicolumn{2}{c}{110.88} \\
\hline
\end{tabular}

According to Tables 1 and 2 and formulae (10) and (11), the ultimate collapse distance and ultimate deflection of each rock stratum are calculated, and the results are shown in Table 3.

4.3. Maximum Free Subsidence Space of Each Rock Stratum and Relevant Calculation. For the free space above the main mining no. 6 coal seam, due to the small roof subsidence before filling, the unfilled roof amount (filling rate of 90\%) and the compression amount of filling body are mainly considered. The equivalent mining height is calculated as $1501 \mathrm{~mm}$. The height of the free subsidence space under the overburden above layer no.12 is calculated by combining formula (15) and Table 1. The results are shown in Table 4.

Combined with Tables 2-4, the ultimate span, ultimate deflection, and free subsidence space height of each layer of overburden are obtained, and the ultimate span and ultimate deflection of overlying strata are determined, as shown in Table 5. The damage scope of overburden strata only develops to the bottom of layer no. 7 glutenite. As there is no free subsidence space, there is no breakage from no. 7 glutenite to the above strata. The maximum height of water flowing fractured zone can be obtained by the total thickness of layers $8-12$ which is $32.5 \mathrm{~m}$. It is concluded.
TABLE 3: The limited span and deflection of overlying strata.

\begin{tabular}{|c|c|c|c|c|}
\hline $\begin{array}{l}\text { Layer } \\
\text { number }\end{array}$ & Lithology & $\begin{array}{c}\text { Layer } \\
\text { thickness (m) }\end{array}$ & $\begin{array}{c}\text { Limited } \\
\text { span } \\
(\mathrm{m})\end{array}$ & $\begin{array}{c}\text { Limited } \\
\text { deflection }(\mathrm{mm})\end{array}$ \\
\hline 3 & Glutenite & 20 & 31.3 & 0.86 \\
\hline 4 & $\begin{array}{c}\text { Sandy } \\
\text { mudstone }\end{array}$ & 5.69 & 21.1 & 1.63 \\
\hline 5 & Glutenite & 27.3 & 38.3 & 1.05 \\
\hline 6 & Coal & 3.07 & 19.2 & 3.16 \\
\hline 7 & Glutenite & 21.97 & 33.3 & 1.56 \\
\hline 8 & Coal & 2 & 15.3 & 2.85 \\
\hline 9 & $\begin{array}{c}\text { Sandy } \\
\text { mudstone }\end{array}$ & 15 & 31.3 & 1.23 \\
\hline 10 & Coal & 2.5 & 17.4 & 3.56 \\
\hline 11 & Sandstone & 8.8 & 31.6 & 1.23 \\
\hline 12 & Glutenite & 4.2 & 21.9 & 2.22 \\
\hline
\end{tabular}

\section{Comparative Analysis of Theoretical Calculation, Empirical Formula, and Numerical Simulation}

5.1. Empirical Formula Calculation. According to the geological data of the mine, the lithology of the overburden is medium hard. The formula for calculating the height of the water flowing fractured zone of the medium hard 
TABLE 4: Free subsidence space of overlying strata.

\begin{tabular}{lccccc}
\hline $\begin{array}{l}\text { Layer } \\
\text { number }\end{array}$ & Lithology & $\begin{array}{c}\text { Layer } \\
\text { thickness }(\mathrm{m})\end{array}$ & $\begin{array}{c}\text { Residual crushing expansion } \\
\text { coefficient, } k_{c i}\end{array}$ & $\begin{array}{c}\text { Backfill space after compaction of } \\
\text { fractured strata }(\mathrm{mm})\end{array}$ & $\begin{array}{c}\text { Height of free sinking } \\
\text { space, } u_{i}(\mathrm{~mm})\end{array}$ \\
\hline 12 & Glutenite & 4.2 & 1.03 & 126 & 1501 \\
11 & Sandstone & 8.8 & 1.03 & 390 & 1374 \\
10 & Coal & 2.5 & 1.06 & 540 & 1111 \\
9 & Sandy mudstone & 15 & 1.06 & 1440 & 661 \\
8 & Coal & 2 & 1.06 & 1501 & 61 \\
7 & Glutenite & 21.97 & 1.03 & - & - \\
\hline
\end{tabular}

TABle 5: Ultimate span, ultimate deflection, and free subsidence space of overlying strata.

\begin{tabular}{lcccc}
\hline Layer number & Lithology & Limited span, $l_{l}(\mathrm{~m})$ & Limited deflection, $W_{l}(\mathrm{~mm})$ & Height of free sinking space, $u_{i}(\mathrm{~mm})$ \\
\hline 7 & Glutenite & - & - & - \\
8 & Coal & 15.3 & 2.85 & 86 \\
9 & Sandy mudstone & 31.3 & 1.23 & 986 \\
10 & Coal & 17.4 & 3.56 & 1111 \\
11 & Sandstone & 31.6 & 1.23 & 1374 \\
12 & Glutenite & 21.9 & 2.22 & 1501 \\
\hline
\end{tabular}

overburden is selected, and the cumulative mining thickness is the equivalent mining thickness of filling. According to the filling mining technical data provided by the mine, the filling rate of layered filling mining is considered as $90 \%$, and the calculation of water flowing fractured zone height based on the "rules for coal pillar setting and coal pressure mining in buildings, water bodies, railways, and main roadways" is shown in Table 6.

From the safety point of view, the maximum development height of water flowing fractured zone is $35 \mathrm{~m}$ according to the empirical formula.

5.2. Numerical Simulation Analysis. Three-dimensional numerical model of mining area is established. The FLAC ${ }^{3 \mathrm{D}}$ calculation model is established according to the geological conditions of the mine, as shown in Figure 12. According to the geological conditions of the mining area, the threedimensional numerical model is established after simplifying the coal strata. The strike length of the model is $300 \mathrm{~m}$, the dip length is $150 \mathrm{~m}$, the height is $121 \mathrm{~m}$, the coal thickness is $3 \mathrm{~m}$, and the buried depth is $144 \mathrm{~m}$. The top of the main key layer is taken as the upper boundary of the model, and the overlying strata are replaced by equivalent loads. $30 \mathrm{~m}$ below the coal seam floor is taken as the lower boundary, the open-off cut and stop mining line extend $60 \mathrm{~m}$ along the strike ( $x$ direction), respectively, as the left and right boundaries of the model, and the working face extends $30 \mathrm{~m}$ along the dip $(y$ direction) as the front and rear boundaries of the model. The design model mining face size is $180 \mathrm{~m} \times 90 \mathrm{~m}$, and the working face is $180 \mathrm{~m}$ along the strike and $90 \mathrm{~m}$ along the dip.

The boundary conditions of the model are shown in Figure 13. In the figure, $\gamma$ is the average bulk density of the overlying strata, taking $2600 \mathrm{KN} / \mathrm{m}^{3}$, and $h$ is the distance from the upper boundary of the model to the surface, taking $54 \mathrm{~m}$. Mohr Coulomb elastic-plastic constitutive model is selected as the mining area model. The mechanical parameters of coal and rock are shown in Table 7. In Table 7,
TABLE 6: The calculation of water flowing fractured zone height $H_{m}$.

\begin{tabular}{lc}
\hline Formula one $(\mathrm{m})$ & Formula two $(\mathrm{m})$ \\
\hline$H_{m}=\frac{100 \sum M}{1.6 \sum M+3.6}$ & $H_{m}=20 \sqrt{\sum M}+10$ \\
$19.4 \sim 30.6$ & 35
\end{tabular}

Note. $\sum M$ is the cumulative mining thickness.
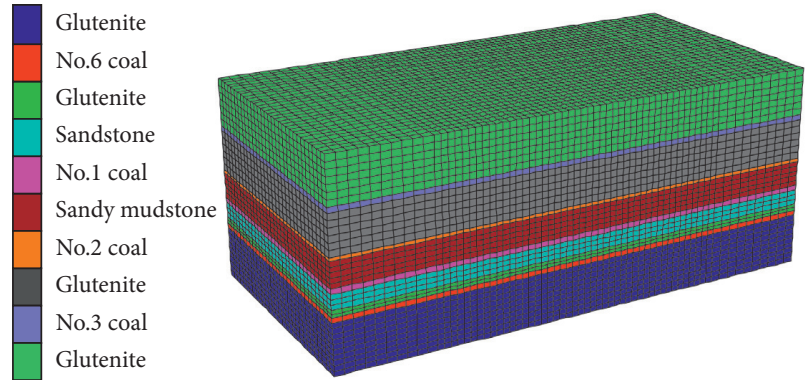

Figure 12: Three-dimensional numerical model of coal mine.

the dead weight of no. 1 to no. 4 strata is replaced by equivalent load. Therefore, only the thickness and bulk density of strata are listed in the mechanical parameters of stratum no. 1 to no. 4 .

For the roadway filling mining in this mine, under the actual $90 \%$ filling rate, the layered roadway filling mining from the bottom to top is adopted for no. 6 coal seam with a thickness of $3 \mathrm{~m}$, which is divided into 5 layers. Considering the construction technology and production efficiency of the roadway and combining with the cross-section form of the existing working face of the mine, the cross-section of the filling roadway is designed to be rectangular: $4 \mathrm{~m}$ wide and $3 \mathrm{~m}$ high. The width of the pillar body is $8 \mathrm{~m}$. From the position of $60 \mathrm{~m}$ horizontal distance from the bottom layer to the left boundary, the roadway shall be excavated and filled in order to complete the first cycle, and then to complete the second and third cycle in turn. After the bottom slicing is 


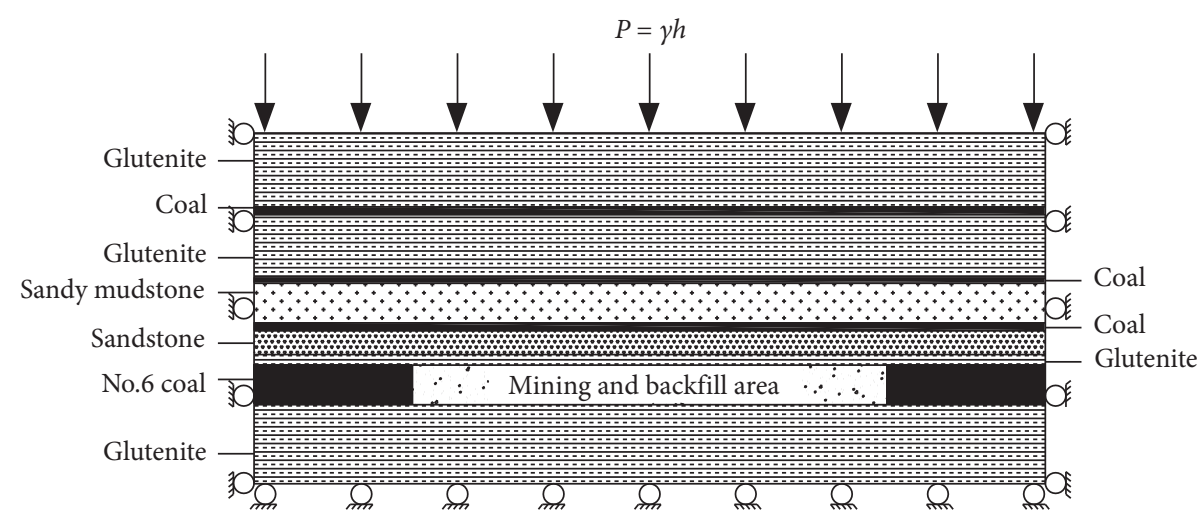

FIGURE 13: Model boundary conditions.

Table 7: Physical and mechanical parameters of coal seam and overlying strata.

\begin{tabular}{|c|c|c|c|c|c|c|c|c|}
\hline $\begin{array}{l}\text { Layer } \\
\text { number }\end{array}$ & Lithology & $\begin{array}{c}\text { Layer } \\
\text { thickness } \\
(\mathrm{m})\end{array}$ & $\begin{array}{l}\text { Bulk density } \\
\left(\mathrm{kN} / \mathrm{m}^{3}\right)\end{array}$ & $\begin{array}{c}\text { Tensile } \\
\text { strength } \\
(\mathrm{MPa})\end{array}$ & $\begin{array}{l}\text { Bulk modulus } \\
\qquad(\mathrm{MPa})\end{array}$ & $\begin{array}{l}\text { Shear modulus } \\
\qquad(\mathrm{MPa})\end{array}$ & $\begin{array}{l}\text { Internal friction } \\
\text { angle }\left({ }^{\circ}\right)\end{array}$ & $\begin{array}{l}\text { Cohesion } \\
\text { (MPa) }\end{array}$ \\
\hline 1 & Topsoil & 5 & 13.8 & - & - & - & - & - \\
\hline 2 & $\begin{array}{c}\text { Gravelly } \\
\text { sand }\end{array}$ & 24 & 24 & - & - & - & - & - \\
\hline 3 & Glutenite & 20 & 26.2 & - & - & - & - & - \\
\hline 4 & $\begin{array}{l}\text { Sandy } \\
\text { mudstone }\end{array}$ & 5 & 25.5 & - & - & - & - & - \\
\hline 5 & Glutenite & 28 & 26 & 1.6 & 2976 & 2049 & 33 & 3.6 \\
\hline 6 & Coal & 3 & 14 & 0.84 & 2083 & 746 & 28 & 1.2 \\
\hline 7 & Glutenite & 24 & 26.4 & 1.7 & 3462 & 2177 & 34 & 3 \\
\hline 8 & Coal & 2 & 14 & 0.82 & 1944 & 795 & 28 & 1.1 \\
\hline 9 & $\begin{array}{l}\text { Sandy } \\
\text { mudstone }\end{array}$ & 15 & 25.8 & 0.9 & 2273 & 1172 & 38 & 1.8 \\
\hline 10 & Coal & 3 & 14 & 0.85 & 1875 & 672 & 28 & 1 \\
\hline 11 & Sandstone & 9 & 26.2 & 1.8 & 5778 & 4333 & 34 & 3.2 \\
\hline 12 & Glutenite & 4 & 26.4 & 1.5 & 2857 & 1967 & 32 & 2.5 \\
\hline 13 & No. 6 coal & 15 & 14 & 0.85 & 2381 & 735 & 28 & 1.2 \\
\hline \multirow[t]{2}{*}{14} & Glutenite & 30 & 26.4 & 1.5 & 3077 & 1935 & 32 & 2.75 \\
\hline & $\begin{array}{c}\text { Backfill } \\
\text { body }\end{array}$ & & 18.2 & 0.85 & 405 & 279 & 23 & 0.85 \\
\hline
\end{tabular}

completely filled and stabilized, the roadway filling mining of the upper layer is carried out. Each cycle roadway is excavated and filled in sequence from left to right.

According to the numerical simulation of the development height of water flowing fractured zone in overburden rock of roadway backfill mining, the plastic zone of overburden failure is shown in Figure 14 and the vertical displacement of overburden rock is shown in Figure 15. It can be seen that with the increase of filling layers, the height of water flowing fractured zone increases from $12 \mathrm{~m}$ in one layer with backfill to $33 \mathrm{~m}$ in five layers with backfill. The height of water flowing fractured zone has a positive correlation with the thickness of accumulative layered backfill mining based on the data presented in Figure 16 which is showed a positive correlation between them.

5.3. Comparative Analysis. Theoretical analysis of overburden fault shows that the height of water flowing fractured zone is $32.5 \mathrm{~m}$, which is less than $35 \mathrm{~m}$ of empirical formula.
The theoretical calculation result is approximately consistent with the height of $33 \mathrm{~m}$ obtained by numerical simulation. It can be seen that the maximum height of water flowing fractured zone calculated by empirical formula is relatively conservative.

According to the height of water conducting fractured zone, the thickness of protective layer, and the thickness of bedrock weathering zone, the required thickness of waterproof coal-rock pillar can be obtained, as shown in Table 8 . Compared with the distance from the aquifer floor to coal seam roof, it can be seen that the thickness of coal and rock pillar $111 \mathrm{~m}$ is greater than the thickness of waterproof coal and rock pillar $39.8 \mathrm{~m}$. Therefore, roadway filling mining is safe and feasible.

Through the filling practice of nearly $300000 \mathrm{~m}^{3}$, roadway backfill mining can effectively control the underground water inflow, save the drainage cost of more than 6 million yuan per year, and reduce the production cost of nearly 20 yuan per ton. The pressure coal resources under the liberated aquifer can reach 3 million tons, the service life of the mine 

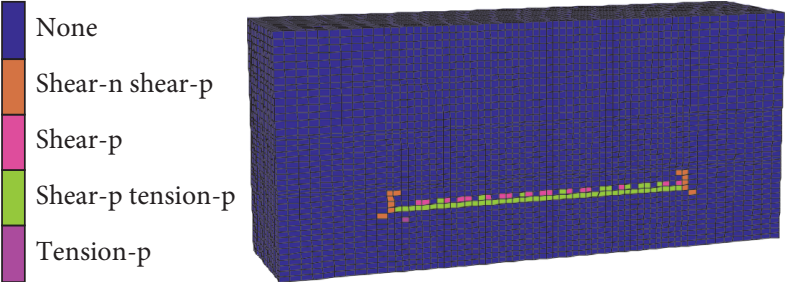

(a)

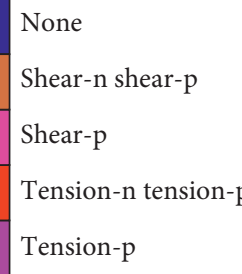

Tension-p

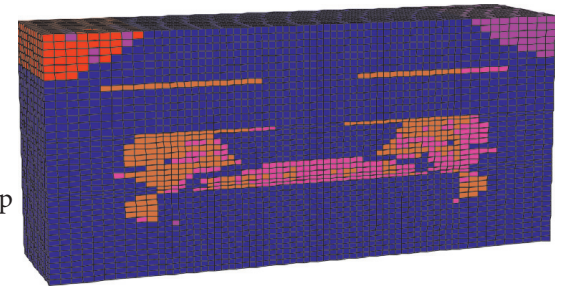

(b)

FIgURE 14: Plastic zone of overburden failure. (a) Mining thickness of one layer, $3 \mathrm{~m}$. (b) Mining thickness of five layers, $15 \mathrm{~m}$.

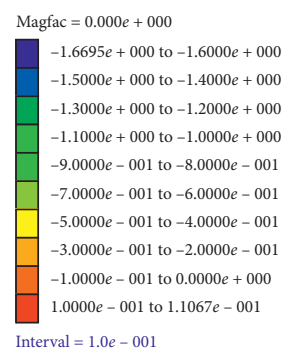

(a)

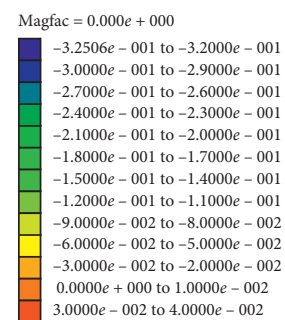

$3.0000 e-002$ to $4.0000 e-002$

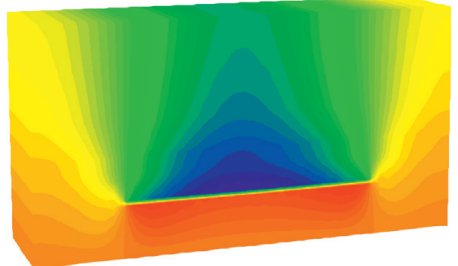

(b)

Figure 15: The vertical displacement of overburden rock. (a) Mining thickness of one layer, $3 \mathrm{~m}$. (b) Mining thickness of five layers, $15 \mathrm{~m}$.

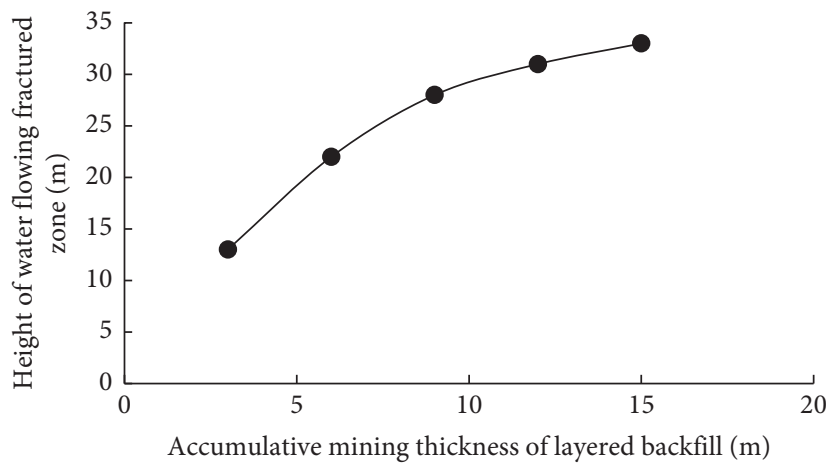

FIGURE 16: Height variation curve of water flowing fractured zone height with accumulative layered backfill thickness.

TABLE 8: Calculation of the waterproof coal-rock pillar, unit: $\mathrm{m}$.

\begin{tabular}{lcccc}
\hline $\begin{array}{l}\text { Height of water flowing } \\
\text { fractured zone }\end{array}$ & $\begin{array}{c}\text { Thickness of } \\
\text { protective layer }\end{array}$ & $\begin{array}{c}\text { Thickness of bedrock } \\
\text { weathering zone }\end{array}$ & $\begin{array}{c}\text { Required thickness of } \\
\text { waterproof coal-rock pillar }\end{array}$ & $\begin{array}{c}\text { Distance from aquifer floor } \\
\text { to coal seam roof }\end{array}$ \\
\hline 32.5 & 1.8 & 5 & 39.8 & 111 \\
\hline
\end{tabular}

can be extended for more than 7 years, and the enterprise can make profits of more than 200 million yuan, and the economic benefits are remarkable.

\section{Conclusion}

A computational model is proposed to explore the stability of overburden rock and the development height of water flowing fractured zone in roadway filling mining. The model is verified with the results of empirical formulae and the numerical simulation method. The following conclusions could be drawn:

(1) The mechanism of overburden movement and deformation and the failure characteristics of overburden rock in roadway backfill mining are studied, and the effect of roadway backfill mining on controlling overburden movement and deformation is analyzed. In the process of driving and filling of roadway in backfill mining, due to the hysteresis of filling and the time required for the solidification of 
the filling body, the overlying strata will produce certain movement deformation and even damage. The better the control effect of strata movement and deformation, the more conducive to maintaining the stability of overburden and controlling the development of water flowing fractured zone while slowing down the subsidence of overburden.

(2) Combined with the equivalent mining height of backfill mining, the development height of overlying rock water flowing fractured zone in roadway backfill mining is analyzed and predicted, and the relevant calculation formula of equivalent mining height of filling is given. The mechanical model of the main roof rock beam is established, and the ultimate span and deflection of the main roof rock beam fracture are deduced. Combined with the stress analysis of the broken rock block of the main roof, the judgment basis is provided for the development of the key overburden strata to the fractured zone.

(3) Combined with roadway filling mining in a mine, it is calculated that the water flowing fractured zone develops to the bottom of layer no. 7 glutenite, and the water flowing fractured zone is $32.5 \mathrm{~m}$, which is similar to the empirical formula and numerical simulation analysis results. The reliability of theoretical calculation is verified by comparative analysis. The thickness of waterproof coal and rock pillar required in the mine is $39.8 \mathrm{~m}$, which can be used for safe roadway filling mining, and has good social and economic benefits.

\section{Data Availability}

The data used to support the findings of this study are available from the corresponding author upon request.

\section{Conflicts of Interest}

The authors declare no conflicts of interest.

\section{Acknowledgments}

This research was financially supported by the National Natural Science Foundation of China (Grant no. 41601593) and the Ph.D. Research Startup Foundation of Shandong Technology and Business University (Grant nos. BS201522 and BS202005).

\section{References}

[1] N. M. Michieka, "Energy and the environment: the relationship between coal production and the environment in China," Natural Resources Research, vol. 23, no. 2, pp. 285-298, 2014.

[2] C. Liu, J. Xue, G. Yu, and X. Cheng, "Fractal characterization for the mining crack evolution process of overlying strata based on microseismic monitoring technology," International Journal of Mining Science and Technology, vol. 26, no. 2, pp. 295-299, 2016.
[3] X. Wei, M. Gao, Y. Lv, X. Shi, H. Gao, and H. Zhou, "Evolution of a mining induced fracture network in the overburden strata of an inclined coal seam," International Journal of Mining Science and Technology, vol. 22, no. 6, pp. 779-783, 2012.

[4] B. Zhang, H. Sun, Y. Liang, K. Wang, and Q. Zou, "Characterization and quantification of mining-induced fractures in overlying strata: implications for coalbed methane drainage," Natural Resources Research, vol. 2, 2019.

[5] S. Wang and L. Ma, "Characteristics and control of mining induced fractures above longwall mines using backfilling," Energies, vol. 12, no. 23, p. 4604, 2019.

[6] G. Zhang, C. Zang, and M. Chen, "Ground response of entries driven adjacent to a retreating longwall panel," International Journal of Rock Mechanics and Mining Sciences, vol. 138, p. 104630, 2021.

[7] L. Nie, H. Wang, Y. Xu, and Z. Li, "A new prediction model for mining subsidence deformation: the arc tangent function model," Natural Hazards, vol. 75, no. 3, pp. 2185-2198, 2015.

[8] W. Cheng, N. Zhang, Y. Han, Z. Xiong, and D. Qian, "Experiment research on overburden mining-induced fracture evolution and its fractal characteristics in ascending mining," Arabian Journal of Geosciences, vol. 8, no. 1, pp. 13-21, 2015.

[9] S. Tian, P. Yang, K. Tang, X. Shen, and F. Shi, "Safety performance of coal mine survey technology using nano-fiber material in coal mining process," Arabian Journal of Geosciences, vol. 13, p. 841, 2020.

[10] Z. Yun, S. Cao, S. Guo, T. Wan, and J. Wang, "Mechanisms of the development of water-conducting fracture zone in overlying strata during short wall block backfill mining: a case study in Northwestern China," Environmental Earth Sciences, vol. 77, no. 14, pp. 1-17, 2018.

[11] K. K. K. Singh, A. K. Bharti, S. K. Pal, A. Prakash, and K. R. Saurabh, "Delineation of fracture zone for groundwater using combined inversion technique," Environmental Earth Sciences, vol. 78, no. 4, 2019.

[12] Y. Zhang, S. Cao, S. Guo, T. Wan, and J. Wang, "Study on the height of fractured water-conducting zone under aquifer for short wall blocking mining," Journal of Mining \& Safety Engineering, vol. 35, no. 1, pp. 7-14, 2010.

[13] P. Bukowski, "Water hazard assessment in active shafts in Upper Silesian Coal Basin mines," Mine Water and the Environment, vol. 30, no. 4, pp. 302-311, 2011.

[14] J. Pope and D. Craw, "Current research on mine water and the environment in New Zealand," Mine Water and the Environment, vol. 34, no. 4, p. 363, 2015.

[15] W. Li, Y. Liu, W. Qiao, C. Zhao, D. Yang, and Q. Guo, “An improved vulnerability assessment model for floor water bursting from a confined aquifer based on the water inrush coefficient method," Mine Water and the Environment, vol. 37, no. 1, pp. 196-204, 2018.

[16] H. Yin, H. Zhao, D. Xie, S. Sang, Y. Shi, and M. Tian, "Mechanism of mine water inrush from overlying porous aquifer in quaternary: a case study in Xinhe Coal Mine of Shandong Province, China," Arabian Journal of Geosciences, vol. 12, no. 5, p. 163, 2019.

[17] Q.-S. Bai and S.-H. Tu, "Failure analysis of a large span longwall drift under water-rich roofs and its control techniques," Engineering Failure Analysis, vol. 67, pp. 15-32, 2016.

[18] H. Zha, W. Liu, and Q. Liu, "Physical simulation of the waterconducting fracture zone of weak roofs in shallow seam mining based on a self-designed hydromechanical coupling experiment system," Geofluids, vol. 2020, pp. 1-14, 2020. 
[19] F. Cui, S. Dong, X. Lai, J. Chen, J. Cao, and P. Shan, "Study on rule of overburden failure and rock burst hazard under repeated mining in fully mechanized top-coal caving face with hard roof," Energies, vol. 12, 2019.

[20] Z. Wen, S. Jing, Y. Jiang et al., "Study of the fracture law of overlying strata under water based on the flow-stress-damage model," Geofluids, vol. 2019, pp. 1-12, 2019.

[21] M. Nasihatgozar, "Analysis of buckling in concrete beams containing nanoparticles utilizing numerical approach," International Journal of Hydro Mechatronics, vol. 2, no. 2, pp. 179-187, 2019.

[22] M. Cinefra, "Numerical method for frequency response in visco-embedded nanoplate," International Journal of Hydro Mechatronics, vol. 2, no. 2, pp. 119-130, 2019.

[23] C. Wang, C. Zhang, X. Zhao, L. Liao, and S. Zhang, "Dynamic structural evolution of overlying strata during shallow coal seam longwall mining," International Journal of Rock Mechanics and Mining Sciences, vol. 103, pp. 20-32, 2018.

[24] A. Majdi, F. P. Hassani, and M. Y. Nasiri, "Prediction of the height of destressed zone above the mined panel roof in longwall coal mining," International Journal of Coal Geology, vol. 98, no. 1, pp. 62-72, 2012.

[25] S. Liu, W. Li, and Q. Wang, "Height of the water-flowing fractured zone of the Jurassic coal seam in northwestern China," Mine Water and the Environment, vol. 37, no. 2, pp. 312-321, 2018.

[26] J. Zhang, X. Miao, and G. Guo, "Study on waste-filling method and technology in fully mechanized coal mining," Journal of the China Coal Society, vol. 35, no. 1, pp. 1-6, 2010.

[27] D. Zhou, K. Wu, X. Miao, and L. Li, "Combined prediction model for mining subsidence in coal mining areas covered with thick alluvial soil layer," Bulletin of Engineering Geology and the Environment, vol. 77, no. 1, pp. 283-304, 2018.

[28] J. Huang, C. Tian, L. Xing, Z. Bian, and X. Miao, "Green and sustainable mining: underground coal mine fully mechanized solid dense stowing-mining method," Sustainability, vol. 9, no. 8, p. 1418, 2017.

[29] J. Zhang, Q. Zhang, Q. Sun, R. Gao, D. Germain, and S. Abro, "Surface subsidence control theory and application to backfill coal mining technology," Environmental Earth Sciences, vol. 74, no. 2, pp. 1439-1448, 2015.

[30] M. Li, J. Zhang, Y. Huang, and N. Zhou, "Effects of particle size of crushed gangue backfill materials on surface subsidence and its application under buildings," Environmental Earth Sciences, vol. 76, no. 17, p. 603, 2017.

[31] N. Zhou, J. Zhang, H. Yan, and M. Li, "Deformation behavior of hard roofs in solid backfill coal mining using physical models," Energies, vol. 10, no. 4, p. 557, 2017.

[32] Q. Zhang, J. Zhang, Y. Huang, and F. Ju, "Backfilling technology and strata behaviors in fully mechanized coal mining working face," International Journal of Mining Science and Technology, vol. 22, no. 2, pp. 151-157, 2012.

[33] X. Zhu, G. Guo, H. Liu, T. Chen, and X. Yang, "Experimental research on strata movement characteristics of backfill-strip mining using similar material modeling," Bulletin of Engineering Geology and the Environment, vol. 78, no. 4, pp. 2151-2167, 2019.

[34] H. Yan, J. Zhang, S. Zhang, and N. Zhou, "Physical modeling of the controlled shaft deformation law during the solid backfill mining of ultra-close coal seams," Bulletin of Engineering Geology and the Environment, vol. 78, no. 5, pp. 3741-3754, 2019.

[35] Y. Huang, J. Zhang, B. An, and Q. Zhang, "Overlying strata movement law in fully mechanized coal mining and backfilling longwall face by similar physical simulation," Journal of Mining Science, vol. 47, no. 5, pp. 618-627, 2011.

[36] J. Yang, Y. Yang, and Y. Chen, "Numerical simulation of smoke movement influence to evacuation in a high-rise residential building fire," Procedia Engineering, vol. 45, pp. 727-734, 2012.

[37] X. Feng and Q. Zhang, “The effect of backfilling materials on the deformation of coal and rock strata containing multiple goaf: a numerical study," Minerals, vol. 8, no. 6, p. 224, 2018.

[38] J. Zhang, Q. Sun, N. Zhou, J. Hai, D. Germain, and S. Abro, "Research and application of roadway backfill coal mining technology in western coal mining area," Arabian Journal of Geosciences, vol. 9, no. 10, pp. 1-10, 2019.

[39] Z. Hou, "Discrimination criterion of main roof of fault zone and its application in shallow coal seam," Acta Coal Sinica, vol. 28, no. 7, pp. 8-12, 2020, in Chinese.

[40] J. Xu, M. Qian, and W. Zhu, "Study on influences of primary key stratum on surface dynamic subsidence," Chinese Journal of Rock Mechanics and Engineering, vol. 24, no. 5, pp. 787-791, 2005.

[41] T. Kuang, Z. Li, W. Zhu et al., "The impact of key strata movement on ground pressure behaviour in the Datong coalfield," International Journal of Rock Mechanics and Mining Sciences, vol. 119, pp. 193-204, 2019. 